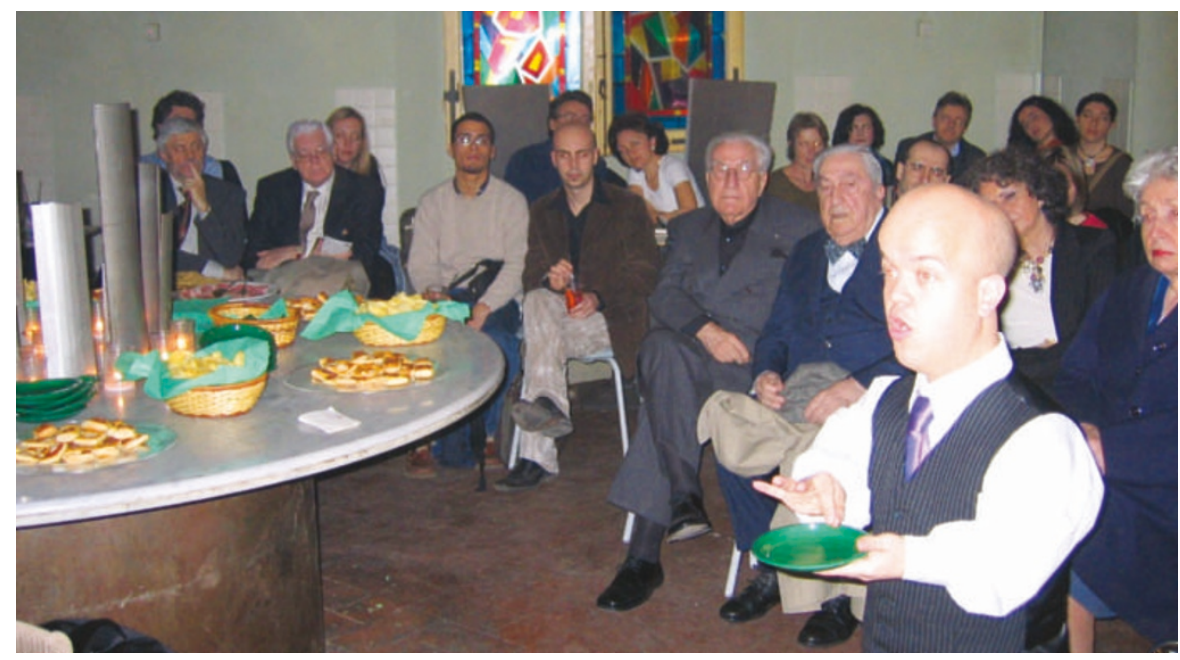

Sweet talk: Tom Shakespeare, a prime mover at Café Scientifique, engages an audience in Bologna, Italy.

\title{
Pop science pulls in public as café culture goes global
}

\section{Jim Giles, Newcastle upon Tyne}

The Vitenskapskafeen in Oslo is so popular that people happily sit on the floor once the seats are taken. The same kind of event, when held in a forest in Poland, attracts everyone from villagers to the local priest. In Denver, Colorado, such meetings draw enough singles to create match-making occasions.

The focus of each of these popular gatherings, called Cafés Scientifique, is informal scientific debate. The idea was started by French physicists in 1997, but when Café Scientifique organizers met to share ideas in Newcastle upon Tyne, UK, on 21 and 22 May they welcomed colleagues from 11 different countries, from Argentina to Japan.

The meeting revealed a movement that has expanded rapidly, but remains close to its grass roots. Suggestions that international cafés could develop a more unified structure and organize larger sources of funding attracted limited interest. Instead members were keen to learn small tricks of the trade from each other.

The events are all based in informal settings, such as bars and cafés. Expert speakers, such as scientists from local universities or businesses, start the meeting with a short talk before joining an audience-led debate. Organizers deliberately keep audiences small, aiming for around 50 participants.

In Britain and France in particular, the proliferation of Cafés Scientifique has been dramatic - the two countries now host around 70 regular events a year between them.

Many of the organizers are eager to see what else they can do with the format; they could, for example, use video conferencing for debates between disparate groups of people. Michael Puncheon, who runs café events as part of his work at the British Council, describes one successful event that linked scientists and lay people in London, Istanbul and Ramallah, on the West Bank near Jerusalem. They were given the chance to hear Mike Parker, an expert in the ethics of genetics at the University of Oxford, discuss issues such as genetic testing. "They were young audiences and they really got stuck in," says Puncheon.

The idea of cafés for young people also attracted interest at the meeting. Since the first such event was run in 1999 in Lyon, France, junior debates have spread to schools in seven French cities. UK organizers say that in the autumn they will apply for funding for a similar programme to the Wellcome Trust, a research charity that encourages public engagement with science. "It's a chance for pupils to meet scientists and businessmen the people who shape the world," says organizer Pablo Jensen, a physicist at Claude Bernard University in Lyon.

Tom Shakespeare, a sociologist at the University of Newcastle upon Tyne who helped organize the meeting, acknowledges that the cafés appeal mainly to the middle class. But Shakespeare and others point out that the events still reach a wide audience, particularly as they can be held in small towns that do not have science museums or universities to host larger events. The cafés also serve an educational function: in France, events have been run in teacher training colleges to make new teachers more confident about discussing science.

The Denver café, organized by University of Colorado immunologist John Cohen, performs another social function: "I know that people have got together after meetings," he says. "So when people come in alone, we carefully direct them to potential partners."

\section{See Editorial, page 327}

www.cafescientifique.org
Britain opens first repository to speed work on stem cells

Laura Nelson, London

Embryonic stem-cell research in Britain is expected to gain impetus from the opening on 19 May of a purpose-built stem-cell bank, just north of London. But despite generous funding and a regulatory framework carefully crafted to encourage the studies, researchers still face obstacles.

Britain established a framework to permit work on stem cells in 2001, but research has moved more slowly than some in the field anticipated. However, biologists are confident that work will go ahead, now support systems are in place.

Britain's approach contrasts with that of the United States, where work on only certain embryonic stem-cell lines gets federal funding. But the difference has yet to set off a flurry of activity in Britain — or to spark a 'brain drain' of US cell biologists, scientists say.

"Stem-cell research is definitely progressing," says Stephen Minger, a researcher in the field at King's College London, "but it's incredibly difficult work. I think the bank will accelerate things."

Minger is one of the first to donate an embryonic stem-cell line to the new bank, which will house embryonic, adult and fetal stem-cell lines, and is located at the National Institute for Biological Standards and Control, Potters Bar.

The bank will make cell lines available to researchers worldwide, and provide British scientists with technical assistance in making use of the lines. Research agencies have allocated $\mathfrak{E} 40$ million (US\$72 million) over three years to support its work.

Anne McLaren, who works on mouse stem cells at the Gurdon Institute in Cambridge, says that researchers are still struggling with the technical and regulatory challenges of stem-cell work.

Before deriving cell lines, researchers must obtain a licence from the Human Fertilisation and Embryology Authority, which takes about a year. Ten research groups have obtained these so far. After that, cell lines take several months to derive. "It does require a certain determination to get through the process," says Robert Terry, a policy adviser at the Wellcome Trust, Europe's largest research charity.

Austin Smith at the Institute for Stem Cell Research in Edinburgh, who obtained the first licence to derive embryonic stem cells, thinks activity in the field will soon pick up. "Things are starting in a serious way," he says. 